\title{
Income Diversification and Household Well-Being: A Case Study in Rural Areas of Bangladesh
}

\author{
Naznin Sultana, Md. Elias Hossain, Md. Khairul Islam \\ Department of Economics, University of Rajshahi, Rajshahi, Bangladesh \\ Email address: \\ nslopa11@yahoo.com (N. Sultana), eliaseco@ru.ac.bd (Md. E. Hossain), khairul06eco@gmail.com (Md. K. Islam)
}

To cite this article:

Naznin Sultana, Md. Elias Hossain, Md. Khairul Islam. Income Diversification and Household Well-Being: A Case Study in Rural Areas of Bangladesh. International Journal of Business and Economics Research. Vol. 4, No. 3, 2015, pp. 172-179. doi: 10.11648/j.ijber.20150403.20

\begin{abstract}
Diversification of income is considered as an effective way to increase household wellbeing in the developing countries. However, scant attention has been given on this issue in the context of Bangladesh. Thus, the objective of this study is to present an empirical evidence of the state of income diversification and its impact on households' wellbeing in the rural areas of Rajshahi district of Bangladesh. To this end a multi-stage random sampling technique is used to select 138 households from the study area. In analyzing the collected data, the Simpson Index of Diversity (SID) is calculated to measure the level of income diversification while household consumption expenditure is used for measuring the level of well-being. Finally, a multiple regression model is employed to determine the factors affecting households' wellbeing. The findings of the study indicate that the extent of income diversification is very low in the study area and it has positive and significant effect on households' wellbeing. The obtained results have important policy implications which imply that programs targeted to engage people in other income generating activities would augment their income sources. As measures from the part of the government reducing the rate of interest for private enterprising in the rural sector, development of rural infrastructure and improving information facilities at the rural areas are suggested.
\end{abstract}

Keywords: Income Diversification, Rural Household, Simpson Index, Household Wellbeing, Bangladesh

\section{Introduction}

Rural households in many developing countries have been found to diversify their income sources that allow them to reduce income related risks and smoothen their consumption (Ellis, 2000; Reardon et al., 1992). This is often necessary in the agriculture based economies where various types of risks exist such as variability in soil quality, crop diseases, price shock, unpredictable rainfall and other weather related events which leads to low productivity, low output and invariably low income which continually trap them in the vicious cycle of poverty. Increasing the sources of income, therefore, has become an important component of livelihood strategies among rural households. According to the portfolio theory of diversification, households generally trade-off relatively high mean profitability of one activity to reduce risk and maximize utility.

Income diversification refers to an increase in the number of sources of income or the balance among the different sources. It means, on the one hand, that total income of a household accrues to more than one sources and on the other hand, no one source is much dominant compared to the other sources (Joshi et al., 2003). Income diversification can also be defined as the process of switching from low value crop production to a high value crop, livestock and non-farm activities. Distinction can be made among growth in crop income, non-crop agricultural income (livestock, fisheries, and forestry) and non-agricultural income, which includes both off-farm wage labor and non-farm self-employment (Escobal, 2001). Income diversification also referred to as a risk management and coping strategy meant to cushion the effects of economic hardship cuts across all workforces in the formal sector (public/private sector), as well as, in the informal sector. For instance studies by Castells and Portes (1989); Ersado (2006); Soares (2005); Minot et al. (2006); Schgtman et al. (2006) discovered that in less developed countries more than 60 percent of the total workforce are engaged in multiple occupations all aimed at cushioning the effects of shocks (economic and agro-climatic), poverty reduction, reduction in income inequality, consumption stability and overall improvement in the standard of living of the households.

Well-being means good quality of life. We may define 
well-being in two ways that is material well-being and social well-being. Material well-being indicates being strong, being in the right frame of mind and looking good while social well-being includes caring for and settling children, having self respect, peace and good relations in the family and the community, having security which include civil peace, a safe and secure environment, personal and physical security and confidence in the future. Well-being also includes having freedom of choice and action which include being able to help other people and community (Narayan et al., 2000a, 2000b).

Bangladesh is predominantly an agricultural economy where agriculture contributes around $19.42 \%$ to the GDP, and about $45 \%$ of the total labor force of the country is dependent directly or indirectly on agriculture. At present, agriculture is growing at $2.46 \%$ per annum and at the same time population is growing at $1.37 \%$ and is expected to be doubled by 2025 (BBS, 2013). That means every year more than 2 million new people will add to our existing population which will require us to increase the productivity of agriculture to ensure adequate supply of food in the future in the context of this probable population growth. Considering this, broad agriculture and rural development sectors have been given the highest priority by the Bangladesh government in order to make the country self-sufficient in food. Besides, agriculture is directly related to the issues like poverty alleviation, rise in the standard of living and increase of employment. Thus, all out efforts of the government have been there to develop the agriculture sector keeping in view the goals set in the $6^{\text {th }}$ Five Year Plan, National Agriculture Policy (NAP) and Millennium Development Goals.

Rajshahi is an agriculture based region which is located in the North West part of the country. Majority of the people of this district live in rural areas which are characterized by inadequate infrastructure, weak marketing facility, poor health, sanitation and education status, absence of sufficient income sources and low standard of living. People of this region are more vulnerable to joblessness and the condition of the people in rural areas is more vulnerable compare to those in urban areas. Without agriculture and agriculture related activities, there is no sufficient employment opportunity in rural areas. Fish culture, livestock rearing and horticulture are the new income sources in rural households but mostly run by rural rich people. Landless and marginal farmers have no such kind of opportunities. However, these occupations are mostly for supplementing family nutrition and cash requirement, and are performed at a low productivity state. Low level of education, lack of skills and proper training force most of the rural households to be engaged in single income source and they have no ability and opportunity to switch to other economic activities. This causes them to migrate from rural subsistence sector to urban based low skill sectors leading to a deteriorating state of the well-being of these rural people.

Thus, it is implied that poverty in Rajshahi district is widespread, particularly in the rural areas. A strategy that succeeds in generating a reasonable rate of growth in real per capita income can shift large number of households above the poverty line. In this connection, diversification of income sources can play a vital role to reduce poverty and increase the level of household well-being in the study area.

Thus, the objective of this paper is to examine the state of income diversification in the rural areas of Bangladesh and to analyze the contribution of income diversification on households' well-being taking the case study of Bangladesh.

\section{Review of Literature}

Extended studied have been done on different aspects and issues related to income diversification. Among them some studies focused on the patterns and determinants of income diversification. Laszlo (2000), Valdivia and Trivelli (1997), Valdivia et al. (1996), and Ahmed et al. (2012) identified the determinants of income diversification among rural farming households. Some of these studies used multiple regression model and some used the Tobit model to achieve the objectives of their research. The result showed that age, level of education of household head and ownership of assets influence income diversification while household size, access to loan and marital status do not affect income diversification. They also found that socio-economic status and access to formal financial market have a positive impact on income diversification. Reardon et al. (1998), Reardon (1997), DeJenvry and Sadoulet (2001), and Elbers and Lanjouw (2001) concentrated on analyzing non-farm income diversification. They all used empirical approaches and found that the non-farm income share was much larger for the rich than for the poor in the rural African households. Reardon et al. (2000) have shown that this was the case in several Latin American countries such as Argentina and Mexico; and also in Ecuador as found by Elbers and Lanjouw (2001). For Asian countries however, Reardon and Barett (2000) showed that the evidence is somewhat mixed with some areas in India and Pakistan, having a smaller share of non-farm income for the wealthiest households. Schwarze and Zeller (2005) and Ahmed et al. (2012) showed that most households were involved in income diversification activities such as petty trading, mat making and tailoring. They suggest that to enhance income diversification it is important to improve rural infrastructure in terms of the provision of electricity and improving access to markets. Minot et al. (2006), Barett and Reardon (2000), Escobal (2001), Adugna (2006), Ersado (2006), De Janvryet et al. (1991) and Kinsley et al. (1998) examined the effects of income diversification on poverty reduction. They focused on empirical relationship between income diversification and its welfare impacts on rural household. Most of these studies found positive feedback of income diversification on household well-being. Minot et al. (2006), Duc et al. (2010) and Ersado (2006) stated found that income diversification is a key way of ex-ante risk management or post risk coping with shocks. Barett and Reardon (2000) also pointed out that diseconomies of scale can, in turn, be caused by land constraints and seasonal variation in agricultural labor productivity, and 
heterogeneous skills in the households. A number of studies also indicate that households in sub-Saharan Africa who are heavily dependent agriculture and agriculture related activities are benefited from income diversification. For instance, income diversification through off-farm activities offer an important route out of poverty, provide higher income earning, increase food consumption, generate employment and reduce income inequality (Escobal, 2001; Adugna, 2006). A review of another empirical study concerning the share of rural non-farm income to total household income showed that household income contributes $29 \%$ of the total income of rural households in South Asia. Thus, there is a strong link between non-farm income share and total household income. Poorer households tend to have less access to non-farm activities than better-off households (Reardon et al., 1998). Studies conducted by De Janvryet et al. (1991) and Kinsley et al. (1998) indicate that income diversification is not only positively correlated with wealth but also with an increased ability to cope with shocks, or in other words, diversification reduces livelihood vulnerability. Diversification is a way for the rural households to insure themselves against the occurrence of such shocks.

\section{Methodology}

\subsection{Measurement of Income Diversification}

There are different methods that can be applied to measure diversification as discussed by Culaset et al. (2005) and Minot et al. (2006). Culaset et al. (2005) used four indices to measure diversification. These are- index of maximum proportion (MI), Herfindahl index, the square of the shares of a firm activity and the Entropy index. Ibrahim et al. (2009), Ijaiyaet et al. (2009), Duc et al.(2010), Minot et al. (2006) and many others used the Simpson Index of Diversity as a measure of income diversification. The Simpson Index of Diversity (SID) is widely used to measure the biodiversity of an ecosystem. The SID may also be interpreted as the probability that two randomly selected organisms will be from the same species. In the present study, we used the Simpson Index of Diversity as a measure of income diversification, which is expressed as follows:

$$
S I D=1-\sum P_{i}^{2}
$$

Where, $\mathrm{P}_{\mathrm{i}}=$ proportion of income coming from $\mathrm{i}^{\text {th }}$ source and SID is a measure of income diversification.

The value of SID always falls between 0 and 1 . If there is just one source of income, i.e., $p_{i}=1$; then SID $=0$. As the number of sources increase, the shares of $p_{i}$ decline, as does the sum of the squared shares, so that SID approaches to 1 . If there are $\mathrm{k}$ sources of income, then the value of SID falls between zero and $1-(1 / \mathrm{k})$. The closer the SID value is to zero, the more will be the level of specialization, and the further it is different from zero, the more will be the level of diversification.

\subsection{Measurement of Well-Being}

Following Ijaiya et al., (2009) descriptive statistics are used in this study to describe the socio-demographic characteristics of the respondents. To measure the level of well-being of the households we used a welfare index where well-being is explained as the amount of consumption expenditure per adult equivalent. The most commonly used definition of adult equivalent is the one given by the Organization for Economic Cooperation and Development (OECD), because of its simplicity of using and wide familiarity. This scale is expressed as follows:

$$
E X P_{e q}=E X P / n^{0.7}
$$

Where, $\mathrm{EXP}=$ total household expenditure, and $\mathrm{n}=$ household size, $0.7=$ exponential formation representing other adults in a particular household (Grootaert and Braithwaite, 1998).

\subsection{Empirical Model}

The general empirical estimation model chosen in the present study to investigate the relationship between income diversification and well-being of the rural households of Rajshahi district, is multiple regression model. Following Minot et al. (2006), the relationship between income diversification and household well-being is shown as.

$$
W B_{i}=\int\left(I D_{i}, H H_{c i}\right)
$$

Where, $\mathrm{WB}_{\mathrm{i}}$ is well-being of the $\mathrm{i}^{\text {th }}$ household. $\mathrm{ID}_{\mathrm{i}}$ is a measure of income diversification of $i^{\text {th }}$ household and $\mathrm{HH}_{\mathrm{ci}}$ indicates the vector of household specific and demographic characteristics, which are household size, distance of local market from residence, age of the household head, number of young members in the family, marital status of the household head, condition of house etc.

According to Ijaiya et al. (2009), the levels and types of income diversification depend upon accessibility and availability of different income sources and in the rural areas they are limited. In that case, people have less opportunity to be engaged in multiple income generating activities. If income sources are limited and people are engaged only with few sources of income then this will have less impact on welfare.

Household size generally has a negative impact on households' welfare (Ijaiya et al., 2009). If the location of residence of the household is far away from the local market, it means reduced welfare of that household compared to the one whose residence is near to the local market. Marital status of household head is supposed to play positive role in household well-being.

Number of young members in the family is an important determinant of household welfare. A family with more young members may increase family income which may increase welfare of family. Housing characteristics $\left(\right.$ houc $_{\mathrm{i}}$ ) is a dummy variable where 1 is assigned for a house which is in good condition (semi pucca and pucca house) and zero otherwise 
(built of mud, thatch, tin, etc).

\subsection{Specification of Empirical Model}

The above model needs to be specified properly for the estimation. It enables us to investigate whether income diversification has positive or negative impact on household well-being. In specifying the model, attention was given on using primary data from cross section of people from the rural areas. Moreover, model specification in the earlier studies was taken into consideration to specify the model for this study. Thus, a multiple regression model (Gujarati, 2003) is chosen, where well-being of the households is taken as the dependent variable while income diversification, number of young members, household size, distance from local market, marital status and house condition are taken as explanatory variables. A linear regression equation that is used by Ibrahim et al. (2009) is adapted for the present study and the specified model is as follows:

$$
W B_{i}=\beta_{0}+\beta_{1} I D_{i}+\beta_{2} \text { Hhs }_{i}+\beta_{3} \text { Dist }_{i}+\beta_{4} \text { Nym }_{i}+\beta_{5} \text { Mstat }_{i}+\beta_{6} \text { Houc }_{i}+U_{i}
$$

Where, Hhs is household size in terms of number of members in the family, Dist is distance of residence from market place, Nym is number of young members in the household, Mstat is marital status of the household head and Houc is the condition of the house expressed as a dummy variable. $\beta_{1}$ and $\beta_{2}$ are parameters to be estimated and $\mu_{\mathrm{i}}$ is the stochastic error term. Drawn from the model, a priori expectations or the expected pattern of behavior of the explanatory variables (income diversification and the vector of household and demographic characteristics) on the dependent variable (well-being) are as follows:

$$
\beta_{1}>0 ; \beta_{2}<0 ; \beta_{3}<0 ; \beta_{4}><0 ; \beta_{5}>0 ; \beta_{6}>0
$$

\subsection{Study Area and Sampling Procedure}

To test whether the above factors influence household well-being, primary data have been used. Required data were collected using direct interview method from nine villages of three unions from Puthia, Paba and Mohanpur upazilas of Rajshahi district. For collecting the data, a multistage random sampling technique is used. Sources from the district level office of agriculture showed that, about $90 \%$ of the households in the study area depend on farming. After listing the farmers in each village, a total of 138 respondents were randomly selected from the villages using simple random sampling procedure. During the data collection, a well structured questionnaire was used where questions were focused on the above mentioned variables.

\section{Results and Discussion}

\subsection{Socio-Demographic Characteristics of the Respondents}

Although consumption expenditure per-adult equivalent is considered as a tool of measuring well-being of the households, there are some major factors that are attributable to well-being. These are- access to health and sanitation, access to fuel and electricity, access to education facilities, membership of social-organizations, having freedom of choice and action, living in better place, access to support services and training for agricultural activities (main economic activity of the rural people), access to credit, taking nutritional diet, etc. In addition, self-sufficiency of the household in food production, access to information and satellite television channels, ability to exercise political rights, empowerment of women etc. have also significant role in improving well-being of the households in the rural areas.

\begin{tabular}{|c|c|c|c|}
\hline \multirow{2}{*}{\multicolumn{2}{|c|}{ Socio Economic Indicators of the Households }} & \multicolumn{2}{|c|}{ Percentage } \\
\hline & & Yes & No \\
\hline \multicolumn{2}{|l|}{ Access to Education } & 91.4 & 8.6 \\
\hline \multicolumn{2}{|c|}{ Membership of Cooperative Society } & 20.3 & 79.7 \\
\hline \multicolumn{2}{|l|}{ Access to Sanitation } & 45.1 & 54.9 \\
\hline \multicolumn{2}{|c|}{ Access to Pure Drinking Water } & 100 & - \\
\hline \multirow{4}{*}{ Access to Health } & Public hospital & 87.0 & 13.0 \\
\hline & Private hospital & 6.5 & 93.5 \\
\hline & Doctor's chamber & 4.3 & 95.7 \\
\hline & Village doctor & 2.1 & 97.9 \\
\hline \multirow{5}{*}{ Condition of house } & Mud and tin & 24.6 & 75.4 \\
\hline & Thatch and tin & 2.9 & 97.1 \\
\hline & Semi pucca & 41.3 & 58.7 \\
\hline & Pucca tin roof & 26.8 & 73.2 \\
\hline & Brick built & 4.3 & 95.7 \\
\hline \multirow{3}{*}{ Fuel Facilities } & Wood & 77.5 & 22.5 \\
\hline & Leaf & 19.6 & 80.4 \\
\hline & Cow dung & 1.4 & 98.6 \\
\hline \multicolumn{2}{|c|}{ Access to agriculture supporting services } & 58.0 & 42.0 \\
\hline \multicolumn{2}{|c|}{ Opportunity of getting Agriculture Training } & 33.3 & 66.7 \\
\hline \multicolumn{2}{|l|}{ Credit Facilities } & 36.2 & 63.8 \\
\hline \multirow{3}{*}{ Access to Energy } & Electricity & 91.3 & 8.7 \\
\hline & Solar panel & 0.7 & 99.3 \\
\hline & Kerosene & 7.2 & 92.8 \\
\hline
\end{tabular}

Table 1. Socio-Economic Indicators of Well-being in the Study Area.

Source: Field Survey

Table 1 presents the socio-economic indicators of the sample households. It is found that the condition of the major indicators of well-being is moderately satisfactory in the study area. Table 1 shows that 91.4 percent households have access to education and 100 percent households have access to pure drinking water. It is found from the field survey that 87.0 percent households have access to public medical facilities and 91.3 percent have access to electricity consumption which are better signs of social welfare. At the same time, 58.0 percent households get help from agricultural organizations in getting various support services whereas 33.3 percent households get agricultural training facility for implementing modern cultivation methods.

In this study, well-being is directly measured by the method that considers consumption expenditure per-adult equivalent. Here, we considered total household expenditure as the household's consumption expenditure which includes 
food, health, education, transport, fuel, and recreation costs. The number of members in the household is converted into adult household member equivalent by converting it with the factor $(n)^{0.7}$, where $\mathrm{n}$ is total number of households. Then, total household expenditure is divided by the number of adult equivalent to get the value of consumption expenditure peradult equivalent. The distribution of household consumption expenditure per adult equivalent is given in Table 2 . In the table, the lower limit of per capita adult equivalent expenditure per year is Tk.10000.00 and the upper limit is Tk. 100000.00

Table 2. Distribution of Households by Annual Consumption Expenditure per Adult Equivalent.

\begin{tabular}{lll}
\hline $\begin{array}{l}\text { Consumption Expenditure (Tk. } \\
\text { Thousands) }\end{array}$ & Frequency & Percentage \\
\hline $10-20$ & 7 & 5.07 \\
$20-30$ & 33 & 23.91 \\
$30-40$ & 24 & 17.39 \\
$40-50$ & 23 & 16.67 \\
$50-60$ & 11 & 7.97 \\
$60-70$ & 13 & 9.42 \\
$70-80$ & 13 & 9.42 \\
$80-90$ & 12 & 8.70 \\
$90-100$ & 2 & 1.45 \\
Total & 138 & 100 \\
\hline
\end{tabular}

According to BBS (2014), the expected per capita income in Bangladesh is around Tk.94000.00 and with a marginal propensity to consume equal to 0.71 at the national level, Tk.66260.00 is spent for consumption per person and Tk.27739.00 is kept for saving purpose. These figures do not match with those found in the study areas. In the study area, only 9.42 percent people were found to spend within the rage between Tk.60000.00 to Tk.70000.00. More than 50 percent people were found to spend Tk.20000.00 to Tk.50000.00 per person per year for consumption purpose due mainly to lower income earnings. There are several reasons for low income and low consumption expenditure in the study area. It is found that income sources in the study area are very limited and almost all income activities are concentrated around agriculture. However, diversification of crop that could result in income diversification, is absent in the study area. The real problem is that rural households have been converting their agricultural land into mango orchards for making more profit although the real picture is different.

Moreover, industrial activities were mostly unavailable in the study area because of the rural setting. Therefore, the degree of income diversification is comparatively low among the households.

\subsection{Annual Average Expenditure of Households by the Level of Income Diversification}

It is believed that income diversification of a household contribute to increase its annual income. If income of a household increases, it can consume more food and non-food goods and services using the additional income. In the present study, the annual average expenditure per adult equivalent for households with different level of income diversification is calculated and it is shown in Table 3. From the table, it is clear that households with higher income diversification have more annual average expenditure per adult equivalent compared to the households with lower income diversification. From Table 3 it is found that there are $14.5 \%$ households which are dependent on only one source of income.

Table 3. Annual Average Expenditure of Households by Level of Income Diversification.

\begin{tabular}{lll}
\hline $\begin{array}{l}\text { Type of Income } \\
\text { Diversification }\end{array}$ & \% of Household & $\begin{array}{l}\text { Average Annual } \\
\text { Expenditure }\end{array}$ \\
\hline No Diversification & 14.5 & 40,132 \\
Low Diversification & 43.5 & 43,156 \\
Medium Diversification & 39.9 & 48,897 \\
High Diversification & 2.2 & 50,143 \\
\hline
\end{tabular}

The annual average expenditure for an adult in these households is Tk.40,132.00. Again, 43.5\% households have low income diversification and their annual average expenditure per adult is Tk.43,156.00. It is obtained that $39.9 \%$ and $2.2 \%$ households belong to the groups of medium and high income diversification, respectively, and their average annual expenditure per adult are Tk.48,897.00 and Tk.50,143.00, respectively.

\subsection{Regression Results}

The results of the multiple regression analysis are presented in Table 4. These results again confirm the link between income diversification and household well-being in Rajshahi district of Bangladesh.

Table 4. Results of Multiple Regression.

\begin{tabular}{lllll}
\hline Variables & Coefficients & Standard error & t-ratio & p-value \\
\hline ID & $0.053^{* *}$ & 0.022 & 2.101 & 0.031 \\
Mastat & 0.194 & 0.244 & 0.796 & 0.428 \\
Houc & 0.034 & 0.050 & 0.683 & 0.496 \\
Dist & $-0.203^{* * *}$ & 0.112 & -1.81 & 0.072 \\
Hhs & $0.086^{* * *}$ & 0.048 & 1.794 & 0.075 \\
Nym & 0.024 & 0.056 & 0.428 & 0.583 \\
Constant & 10.229 & 0.859 & 11.902 & 0.000 \\
\hline
\end{tabular}

R-Square $=0.634$, Adjusted R-Square $=0.592, \mathrm{~F}-$ Ratio $=1.986,{ }^{*}, * *$ and *** indicate $1 \%, 5 \%$ and $10 \%$ level of significance

It is found in the table that R-squared value of the estimated regression is 0.634 . This means that $63.4 \%$ variation in the dependent variable (well-being) is explained by the explanatory variables (income diversification and vector of household and demographic characteristics of the respondents) in the case of Rajshahi, while the error term takes care of the remaining $36.6 \%$ variations. The positive sign of the coefficient of variables indicates that there is positive relationship between well-being and these explanatory variables. Again, the negative sign implies an inverse relationship between the household well-being and 
the variables.

From Table 4 it is found that the coefficient of income diversification is positive and significant. The value of the coefficient 0.053 reveals that for an increase of each additional source of income, well-being of the household increases by 0.053 units. Similarly, household size has also positive effect in enhancing well-being of the households, which is contrary to our prior expectation. However, this is not unrealistic considering the reality of the rural areas of Bangladesh. As most of the households in rural areas are basically involved with agriculture, having more family members may mean more household labor to work in the field and thus result in more production and render higher welfare. The coefficient value 0.086 means that each additional member in the family would add 0.086 unit of welfare to the family. This is also supported by the positive coefficient of the variable $\mathrm{Nym}$ which is positive although not significant. Other variables- marital status and house condition bear expected signs but did not appear to be significant. Thus, from the regression results it can be concluded that there exists positive relationship between income diversification and household well-being in the rural areas of Bangladesh.

\section{Conclusion and Policy Implication}

Income Diversification is considered as the most important strategy for raising income and reducing rural poverty in Bangladesh. From the above findings it is clear that income diversification has significant impacts on households' wellbeing in Rajshahi District. However, the extent of income diversification is comparatively low in the study area. The reason behind this is that most of the people living in the rural area are vulnerable as they depend only on agriculture related activities for their livelihood and they are subject to different types of risks (natural disaster) like drought, scarcity of irrigation water, non availability of other income sources, etc. Although, forestry, gardening, fish culture, livestock rearing and petty business are the new sources of income emerged to the rural households, these activities are mostly run by the rich farmers. Landless and marginal farmers have no such kind of opportunities. Demographic and household characteristics are also significant determinants of income diversification, which in turn, determine household wellbeing in the study area, as was seen from the regression results.

For increasing the extent of income diversification it is necessary to provide incentives for entrepreneurial development among the people in the study area. Several steps need to be taken for this. Firstly, it is needed to encourage small-scale businesses in the rural area that could be additional sources of income to the people. Secondly, expansion of existing credit market, development of infrastructure and improvement of information facilities are needed that would allow for diversifying income generating activities in the study households. Thirdly, steps should be taken to reduce the rate of interest charged by the credit providing institutions (banks, co-operative societies and money lenders), develop better transport and communication networks and provide electricity to help increase the rate of income diversification in the rural areas. The development of rural roads and communications reduces the transaction cost associated with acquisition of farm inputs and sale of farm products. This enables farmers to buy farm inputs at lower prices and sell their produce at competitive prices. Fourthly, government should also establish institutions and encourage formation of cooperatives that offer micro-finance and loans to farmers in order to mobilize savings and maximize the availability of credit to the farmers.

\section{Appendix}

Table I. ANOVA for the Full Model of Multiple Regressions.

\begin{tabular}{|c|c|c|c|c|c|c|}
\hline \multicolumn{7}{|c|}{ ANOVA(b) } \\
\hline Model & & Sum of Squares & Df & Mean Square & $\mathbf{F}$ & Sig. \\
\hline \multirow{3}{*}{1} & Regression & 5.38 & 7 & .769 & 1.886 & .077 \\
\hline & Residual & 52.98 & 130 & .408 & & \\
\hline & Total & 58.36 & 137 & & & \\
\hline
\end{tabular}

a. Predictors: (Constant), Income diversification, Household size, Distance of market from house, Marital status, Housing condition and Number of young members in family.

b. Dependent Variable: Household Well-Being

Table II. The Full Model Summary of Multiple Regressions of Factor Affecting Household Well-being.

\begin{tabular}{llllll}
\hline Model Summary $(\mathbf{b})$ & & & & \\
\hline Model & R & R Square & Adjusted R Square & Std. Error of the Estimate & Durbin-Watson \\
\hline 1 & .917 & .634 & .592 & .63839 & 2.061 \\
\hline
\end{tabular}

a. Predictors: (Constant), Income diversification, Household size, Distance of market from house, Marital status, Housing condition and Number of young members in family

b. Dependent Variable: Household Well-Being 
Table III. Colinearity Statistics of Household Well-being.

\begin{tabular}{lllll}
\hline \multirow{2}{*}{ Variability } & Co linearity Statistics & & & Eigen value \\
\cline { 2 - 5 } & Tolerance & VIF & .793 & 2.755 \\
\hline ID & .896 & 1.116 & .371 & 4.025 \\
Mastat & .888 & 1.126 & .234 & 5.065 \\
Houc & .906 & 1.104 & .077 & 8.815 \\
Dist & .822 & 1.217 & .033 & 13.563 \\
Hhs & .869 & 1.151 & .002 & 49.537 \\
Nym & .820 & 1.219 & \\
\hline
\end{tabular}

Note: ID = Income diversification, Mastat $=$ Marital Status Houc $=$ House condition, Dist $=$ Distance from local market, $\mathrm{d}$ Hhs $=$ Household size and Nym $=$ number of young members in family.

Table IV. Residuals Statistics of Household Well-being.

\begin{tabular}{llllll}
\hline Residuals Statistics(a) & & & & & Std. Deviation \\
\hline & Minimum & Maximum & Mean & N \\
\hline Predicted Value & 10.1941 & 11.1448 & 10.6988 & .19817 & 138 \\
Residual & -1.22821 & 2.63524 & .00000 & .62186 & 138 \\
Std. Predicted Value & -2.547 & 2.251 & .000 & 1.000 & .974 \\
Std. Residual & -1.924 & 4.128 & .000 & .90 & 138 \\
\hline
\end{tabular}

a. Dependent Variable: Household Well-Being

The figures below present Histogram, P-P plot and Scatter plot of Regression standardized residuals showing the non-linear distribution of data and heterogeneity of variances.

\section{Histogram}

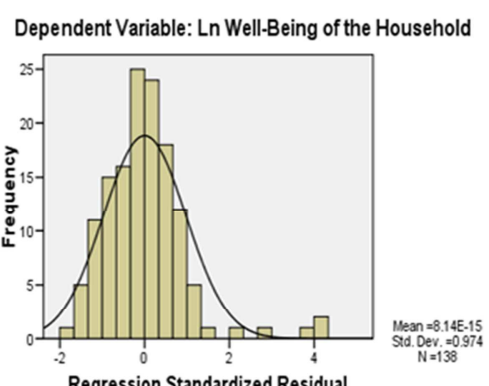

Normal P-P Plot of Regression Standardized Residual

Dependent Variable: Ln Household Well-being

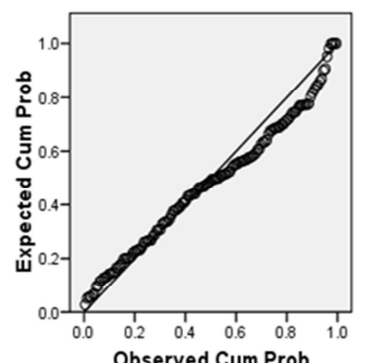

Scatterplot

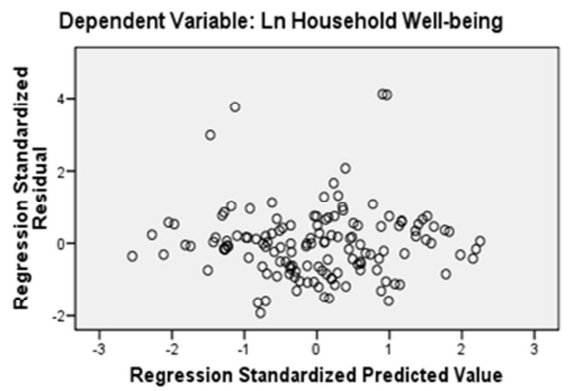

Figure 1. Histogram, P-P plot, and Scatter plot of Regression standardized residuals.

\section{References}

[1] Adugana, L. (2006). The dynamics of income diversification in Ethiopia, www.ideas.repec.org/mab/wpapers/3.html.

[2] Ahmed, and Fausat F. (2012).Income diversification determinants among farming households in Konduga, Borno State, Nigeria, Academic Research International, Vol. 2, No. 2, March 2012.

[3] Barret, C.B., and Reardon, T. (2000). Asset, activity and income diversification among African agriculturalists: some practical issues, www. Ieswise.edu/itc/live/basglooo3a.

[4] Barret, C.B., Reardon, T. and Webb, P. (2001). Non-farm income diversification and household livelihood strategies in rural Africa: Dynamics and policy implications, Food policy, 26 (4), 315-331.

[5] BBS, (2013). Yearbook of Agricultural Statistical of Bangladesh. Bangladesh Bureau of Statistics, Ministry of Planning, Government of the People's Republic of Bangladesh, Dhaka, Bangladesh.
[6] BBS, (2014). Yearbook of Agricultural Statistical of Bangladesh.Bangladesh Bureau of Statistics, Ministry of Planning, Government of the People's Republic of Bangladesh, Dhaka, Bangladesh.

[7] Castells, M. and Portes, A. (1989). World underneath: The origins, dynamics and affects of the informal economy.

[8] De Janvry, A. and Sadoulet, E. (2001). Income Strategies among rural Households in Mexico: The role of off-farm activities. World Development Vol. 29, No. 3, pp.467 480.

[9] De janvry, a., m. Fafchamps and e. Sadoulet (1991). Peasant household behavior with missing markets: some paradoxes explained. Economic journal 101: 1400-1417.

[10] Duc, P.T. and Waibel, H. (2009). Diversification, risk management and risk coping strategies: Evidence from rural households in three provinces in Vietnam, proceedings of the German Development Economics conference, Frankfurt a. M. 2009, No. 25.

[11] Elbers, C. and Lanjouw, P. (2001). Intersectoral transfer, growth and inequality in rural Ecuador.World Development, 29(3): 481-496. 
[12] Ellis, F. (2000). Rural livelihoods and diversity in developing Countries.Oxford University Press, Oxford.

[13] Ersado, L. (2006). Income Diversification in Zimbabwe: Welfare implications from urban and rural Areas. World Bank Policy Research Working Paper No.3964, July. The World Bank, Washington, DC.

[14] Escobal, J. (2001). The determinants of non-farm income diversification in rural peru. World development, 29 (30): 497 508 .

[15] Grootaert, C. (1986). Measuring and analyzing levels of living in developing countries: An annotated questionnaire, World Bank living standard measurements study working paper no. 24.

[16] Gujarati, D. N. (2003). Basic Econometrics, McGraw-Hill, New York, USA.

[17] Ibrahim H. Rahman, EnvulusS.A, Oyewole S.O. (2009). Income and crop diversification among farming households in a rural area of north central Nigeria.Journal of Tropical Agriculture, Food, Environment and Extension. Volume 8, Number 2, pp. 84 -89.

[18] Ijaiya, G.T. (2006). Good governance and poverty reduction in Nigeria: A framework for policy, Journal of social and economic policy, 3(1), 47-58.

[19] Ijaiya, Gafarat. Ijaiya, Raji A. Bello, Muftau A. Ijaiya (2009). Income Diversification and Household Well-Being in Ilorin Metropolis, Nigeria. International Journal Of Business Management Economics and Information Technology Vol.1, No.1, January-June 2009: 1-12.

[20] Joshi, P.K., Gulati, A.A., Birthal, P.S. and Twari, L. (2003). Agriculture diversification in South Asia: Pattern, determinants and policy implications. Discussion paper no. 57 Market structure studies division. International food policy Research Institute. Washington D.C.

[21] Kinsley, b., k. Burger and j.w. gunning (1998): coping with drought in zimbabwe: survey evidence on responses of rural households to risks. In: world development 26(1): 89-110.

[22] Laszlo, S. (2000). Labor supply and the household enterprise. The case of non-farm self employment in rural Peru, Unprocessed, Department of Economics, University of Toronto.

[23] Minot, N., Epprecht, M., Anh, T.T.T. and Trung, L.Q. (2006). Income diversification in the northern uplands of Vietnam: Research report No.145. International food policy research institute, Washington D.C.

[24] Narayan D., Chambers R., Shah M.K., and Petesch P. (200b). Voices of the poor: crying out for change, New York: Oxford University Press.
[25] Narayan D., Peter R., Schaffc K., Rademacher A., and KochSchulte S. (2000a). Voices of the poor: Crying out for change, New York: Oxford University Press, New York.

[26] Reardon, T., Stamouis, K.A., Balisacan, M.E.C., Berdegue, J. and Banks, B. (1998). Rural non-farm income in developing countries. In: FAO (ed.). The state of Food and Agriculture. PP 281-356.

[27] Reardon, T and Barrett, C.B. (2000). Agro industrialization, globalization and international development: an overview of issues, patterns and determinants. Agricultural Economics.

[28] Reardon, T. (1997). Using evidence of household income diversification to inform study of the rural non-farm labor market in Africa. World Development, 25(5), 735-748.

[29] Reardon, T., C. Delgado, and P. Matlon. 1992. Determinants and effects of income diversification amongst farm households in Burkina Faso. Journal of Development Studies, 28 (January1992), pp. 264-296.

[30] Reardon, T., Cruz, M.E., Berdegue, J. (1998). Invited plenary paper at the TercerSimposioLatinoamericano de Investigation y Extension en SistemasAgropecuarios, Lima, 19-21 August.

[31] Reardon, T., Taylor, J.E., Stamoulis, K., Lanjouw, P. and Balisacan, A. (2000). Effects of non-farm employment on rural income inequality in developing countries: An investment perspective. Journal of Agriculture economics, 51(2), May, 266-288.

[32] Richard, Culas and Mahen, M. (2005). Causes of Diversification in Agriculture over Time: Evidence from Norwegian farming sector. Working paper No: 24647, International Congress, August 23-27, 2005, Copenhagen, Denmark.

[33] Schgtman A., Berdegue J. and Modrego F. (2006). Income Diversification through Agricultural Development.

[34] Schwarze, S. and Zeller, M. (2005). Income diversification of rural households in Central Sulawesi, Indonesia.Quarterly Journal of International Agriculture 44 (2005), No. 1: 61-73.

[35] Soares, F.V. (2005). The impact of trade liberalization on the informal sector in Brazil. UNDP International Poverty Centre, working paper no. 7 .

[36] Trivelli, C. (1997). Credito en los hogaresruralesdelperu. SereiInvestigacionesBreves, 4, Lima: CIE.

[37] Valdivia, M. (1997). Mercados de trabajo y manejo de riesgo en economiasrurales: evaluacion de los hogares de pomacanchi, Cuzco. Unprocessed Lima, GRADE.

[38] Valdivia. C., Dunn, E. and Jette, C. (1996).Diversification as a risk management strategy in an Andean agro pastoral community, American Journal of Agric Economics, 78(5), 1334. 